\title{
Socio-economic factors influencing the adoption of low carbon technologies under rice production systems in China
}

\section{Zhong-Du Chen}

China national rice research institute

fu chen ( $\nabla$ fuchen196409@126.com)

China agricultural university

\section{Research}

Keywords: Farmer household, Climate change, Poisson estimators, Multivariate probit, Interdependent, Southern China

Posted Date: March 12th, 2020

DOI: https://doi.org/10.21203/rs.3.rs-16975/v1

License: (c) (i) This work is licensed under a Creative Commons Attribution 4.0 International License.

Read Full License 
1 Socio-economic factors influencing the adoption of low carbon technologies under rice production systems in China

3

4 Zhong-Du Chen ${ }^{\mathrm{a}, \mathrm{b}}, \mathrm{Fu}$ Chen $^{\mathrm{b}}{ }^{*}$

5

$6 \quad{ }^{a}$ China National Rice Research Institution, Hangzhou, 310006, China

$7 \quad{ }^{\mathrm{b}}$ College of Agronomy and Biotechnology, China Agricultural University; Key Laboratory of Farming 8 System, Ministry of Agriculture of China, Beijing 100193, China

9

*Corresponding author, fuchen196409@126.com. Tel: +86 10 62733316; Fax: +86 10 62733316. Full

11 postal address: College of Agronomy and Biotechnology, China Agricultural University, No.2

12 Yuanmingyuan West Road, Haidian District, Beijing 100193, China

13

14 


\section{ABSTRACT}

[Background] Rice (Oryza sativa L.) is the prominent cereal crop in Hunan Province (HP), which is a major rice production area in China. Rice production, such as farmers' livelihood and the soil quality, has been identified to be influenced by climate change. Low carbon technologies (LCTs) have been identified to tackle agricultural challenges; however, the benefits of LCTs for farmers in rice production are still debatable. The choice of potential LCTs relevant to the case study is based on a literature review of previous empirical studies. Thus, the objective of the study were to 1) investigate the public perception and preferences of LCTs in rice production of HP, and 2) analyze the influences of the factors on farmer's decision in adopting LCTs in rice production. There were 555 farmer surveys from eight representative rice production counties in HP, both the poisson estimators and multivariate probit (MVP) approach were applied in the study. [Results] Our results show that water-saving irrigation, integrated pest management techniques and planting green manure crops in winter season were the three major LCTs adapted by farmers in rice production in HP. Both the intensity and probability of the adoptions of LCTs were affected by the main factors including farmers' education level, climate change awareness, machinery ownership, technical support and subsidies. There is a significant correlation among the LCTs, and the adoption of the technologies is interdependent, depicting either complementarities or substitutabilities between the practices. [Conclusions] This study suggests that policies enhance the integration of LCTs would be central to farmers' knowledge, environmental concerns, technical service and financial support in rice production systems in China.

\section{Keywords}

Farmer household

37 Climate change

Poisson estimators

39 Multivariate probit

40 Interdependent

41 Southern China 


\section{Background}

Global climate change, associated with more extreme climate events, has been identified to increase the risks of floods, drought, and fire [1]. Agriculture is easily influenced by climate shifts, and predicted happened with relevant factors including redistribution of water availability and compromised quality, increased soil erosion, and decreased crop productivity [2, 3]. These factors present immediate and localized economic risks to farmers. In contrast, emissions of greenhouse gases (GHGs) pose potential threats to the larger landscape over a long time. Moreover, agriculture is the major source of the GHGs that are driving those changes, contributing about $60 \%$ and $58 \%$ of the total anthropogenic emissions of methane $\left(\mathrm{CH}_{4}\right)$ and nitrous oxide $\left(\mathrm{N}_{2} \mathrm{O}\right)$, respectively. With regard to $\mathrm{CH}_{4}$, rice (Oryza sativa L.) production remains the largest emission source from a single sector and accounts for $18 \%$ of total agricultural $\mathrm{CH}_{4}$ emissions [4]. Thus, climate change threats rice production systems, which represent negative effects to quality of life at local and global scales. Therefore, development strategies of adaptation and mitigation for rice production systems is an urgent issue currently $[2,3,5]$.

China is the largest rice producer in the world, accounting for $16 \%$ and $28 \%$ of the global rice area and global rice production [6]. Hunan Province (HP) is the largest rice producing region in China, accounting for $14 \%$ of China's rice production [7]. Thus the rice production in HP is very important in China's food security. However, rice production is very sensitive to climate change with the increasing of rice acreage during recent decades in HP [7]. The uneven spatial and temporal distribution of precipitation in HP, especially during July and October when rice is in large water demand, high evaporation and low precipitation always lead to drought, in addition with poor irrigation infrastructure, which generally influenced the rice production. On the other hand, soils continue to deteriorate as a result of increased chemical fertilizer input, decreased organic fertilizer input, little application of green manure and soil erosion. According to a document released by Chinese government, the formulation and implementation of policies in adaptation to climate change have received high priority $[8,9]$. In addition, the local governments in HP had released a notification "The Thirteen Five-year Plan for Low Carbon Development of Hunan province”, in order to build up low-carbon agriculture production systems. However, current knowledge about how to do farm management to implement these governmental plans is insufficient since previous studies were mostly either based on qualitative analysis or concentrated on other regions [7].

Generally, the optimized management strategies in agricultural systems have been identified to be 
useful to mitigate the GHG emissions, many of current applied technologies that can be implemented immediately $[4,10,11]$. However, most analysts were mainly concentrated on single technologies (e.g. nitrogen management, conservation tillage, or water-saving irrigation) adopted by farmers, which ignored the complementarities and/or substitutabilities of different technologies [12]. The extent of adoption of LCTs is measured by the number of component technologies adopted by rice farmers, which is more complex than the decision to adopt a single technology. The single decision is usually based on short-term profitability considerations, while interrelated adoption implies a more substantial and longer-lasting change in farming conservation [13, 14]. Moreover, technologies had been developed and disseminated as a package with several components by many scientists [15, 16]. Although previous studies have investigated the adoption of technology packages $[17,18]$, however, these studies are under the background of western countries where integrated management practices are usually adopted in dairy farming. Hence, the uniqueness evaluation of the package of technology is a major contribution of this study that had little studies on the adoption of LCTs investigation in rice farming in China. Therefore, the objectives of this study were 1) to investigate the application level of LCTs by farmers to cope with climate change in rice production in HP of China; 2) to examine factors that affect the likelihood of farmers' adoption intensity of selected LCTs by farmers in rice production; 3) to examine the effects of policy supports and household characteristics on farmers' decisions in applying different LCTs in order to mitigate the effects of climate change, and considering the possibilities of adoption of different LCTs simultaneously.

\section{Study areas}

Hunan province (HP) is located in Southeast China $\left(24^{\circ} 39^{\prime}-30^{\circ} 08^{\prime} \mathrm{N}, 108^{\circ} 47^{\prime}-114^{\circ} 15^{\prime} \mathrm{E}\right)$, which has a subtropical humid monsoon climate with an average annual air temperature of 16.418.5which mean precipitation of 1200-1700 mm (Liu et al., 2015), 80\% of which falls during the rice growing season from April to November. There are nearly 272-300 frost-free days and about 9 months with mean temperature above $10 \mathrm{~g}$ season from April to November. The province is one of major double rice cropping system provinces in China with $1.5 \times 10^{6}$ ha double rice planting area in 2014. It was divided into three areas as follows: the northern commodity economy type, the central and eastern suburban type, and the southern export-oriented type. Eight representative counties were selected in this study, including Changde, Yiyang, Yueyang, Changsha, Zhuzhou, Shaoyang, Hengyang and 
Chenzhou (Fig. 1). The selection of the representative counties was based on the climate conditions, natural resources, soil fertility statue, socioeconomic conditions, geographic location and rice yield level amongst counties. The soil productivity statue was judged by the famers according to soil fertility, soil moisture content and topography in each field. Hengyang and Chenzhou in the south of HP represent the low fertility soil areas with low water resources, where the economic conditions are less developed. Changsha, Zhuzhou and Shaoyang in the central and eastern of HP represent the high fertility soil areas with high water resources, where the economic conditions are much better than other cities.

\section{Data sources}

\section{Selection of low carbon technologies for the case study}

A review of agronomic experimental evidence in previous publications and studies shed some insight into discovering how LCTs help to reduce GHG emission. Retrieved from a keyword search of "mitigation/agriculture" in major scientific database platforms such as Web of Science, SciFinder Scholar and Google Scholar, previous studies that report successful agricultural practices in different regions that obtain higher mitigation potential in terms of soil carbon sequestration rate were collected. Table 1 shows the selection of these practices and the main sources of literature. Eighteen experts from research institutes and universities of regional and national levels were invited to evaluate and prioritize the practices identified in the above procedure with reference to socio-economic and environmental criteria. In choosing experts, the following guidelines were followed: 1) a minimum of 5 years' working experience on issues related to GHG mitigation in agriculture; 2) sufficient knowledge of the different cropping management and systems so that the expert is able to cope successfully with the selected mitigation practices contained in the survey; 3) regular contact with farmers and extensive knowledge of the productive sector is prioritized. Apart from the survey of experts, the farmers were also asked to complete questionnaires containing selected practices from the literature review. The aim of the survey of farmers is to assess the current barriers to the adoption of the above practices in the case study area of HP. Though the survey of farmers also includes what other relevant mitigation measures adopted by them are, it gains no significant responses. The study of mitigation practices has 
134

The LCTs survey was a multiphase survey of rice farms in eight counties of HP in the present study. In terms of sampling, stratified random sampling was adopted with four parts of questionnaire including 1) overall information about the household and the household head; 2) farmer's attitude towards climate change, low carbon agriculture and risk; 3) characteristics of the farmer's filed; 4) external environment characteristics. The selection of variables has considered both economic theory and previous similar studies that conducting the adoption measures against climate change $[19,20]$. There were 40 representatives were conducted as pre-tested at Swan village, Ningxiang county of HP in order to test the reasonability of the questionnaire. Finally, the questionnaire was efficiently improved based on the comments and suggestions. The reliability analysis was calculated by the Cronbach's Alpha method, the results showed the Cronbach's alpha coefficient were all over 0.7 , which indicates that the data has good internal consistency of questionnaire and survey results have a high credibility. Finally, two townships in each county and two villages in each township for field surveys were randomly selected. Moreover, in each village, 20 farm households were randomly selected and interviewed. The interviews were carried out among rice farmers during the period June-October 2013 and 2014. A 640 investigate dataset was collected from farmers across all eight counties. Ultimately, 555 surveys were finally used in the present study, which provided all information.

\section{Data and variable definition}

Explanatory variables used in the econometric model and their expected signs are given in Table 2. Prior expectations about the relationships between the explanatory variables and the technology adoptions are based on theoretical underpinnings and from previous empirical results. On average, the age of rice farmers was around 50 years old, and rice farmers have approximately 6 years of formal schooling, 19 years of rice farming experience and 4 household members in HP. Farmers in this region have less on-rice income, accounted for approximately $25 \sim 49 \%$ of total revenue. The most of rice farmers in HP are more risk-averse, and lack of awareness of low-carbon agriculture. Each rice farmer has an average of 4 ha farm acreage, and very few rice farmers achieve farm mechanization, although they have a better supply of irrigation water in Hunan province. About $61 \%$ the rice farmers think their paddy soil is barren and unproductive. In addition, the famers in Hunan province find it difficult to obtain bank credit and technical support from government. It is notable that only $5 \%$ of the sample 
participated in on-farm demonstrations, and $10 \%$ of sample received training and technical assistance from government organization. About $61 \%$ rice farmers had achieved technology subsidies in this region.

\section{Methods}

\section{Estimation of count data models}

Low carbon technologies are characterized by a number of component technologies which can be adopted in sets by the farmer [21]. Thus, some farmers may adopt one or a few components, whereas others may adopt several or many components. The Poisson regression model can be considered the starting point for count data analysis, which was better used to predict the number of occurrences of the event of interest and the adoption of the selected LCTs in the present study. The dependent variable of the model (y) is a count of the number of LCTs adopted by farmers in a particular period; that is, $y=0$, $1,2,3 \ldots \ldots, \mathrm{N}$. If y is a Poisson random variable, then its probability density function can be represented as [Eq. (1)]:

$f\left(\mathrm{y}_{\mathrm{i}} / \mathrm{x}_{\mathrm{i}}\right)=\mathrm{P}\left(\mathrm{Y}_{\mathrm{i}}=\mathrm{y}_{\mathrm{i}}\right)=\frac{\mathrm{e}^{\lambda} \lambda^{\mathrm{y}}}{\mathrm{y} !}, \quad \mathrm{y}=0,1,2,3 \ldots \ldots \ldots, \mathrm{N}$

Where $y_{i}$ is the number of LCTs adopted by farmer $i$ and $x_{i}$ are variables that affect the adoption of these practices. The factorial parameter $\mathrm{y}$ ! is y factorial $=\mathrm{y}^{*}(\mathrm{y}-1) *(\mathrm{y}-2) * 2 * 1$, whereas the expected mean parameter $(\lambda)$ of this probability function is defined as follows:

$\lambda_{\mathrm{i}}=\mathrm{E}\left[\mathrm{y}_{\mathrm{i}} \mid \mathrm{x}_{\mathrm{i}}\right]=\exp \left(\mathrm{x}_{\mathrm{i}}\right) \beta$

The Poisson regression model is estimated by maximum likelihood. Some important conclusions are derived from the marginal effect concept, meaning that the change in the conditional mean of $y$ when the regressors $\mathrm{x}$ change by one unit [Eq. (3)]:

$\frac{\partial E\left[y_{i} \mid x_{i}\right]}{\partial x_{i}}$

A negative binomial analysis as a statistical test has been carried out to allow an adjustment for the presence of over-under dispersion (variance of $\mathrm{y}_{i}$ greater or lower than its mean value) after running a Poisson regression. Over dispersion might mean that the regression experiences problems with inconsistency, deflated standard errors and grossly inflated t-statistics in the maximum likelihood output. 


\section{Estimation of multivariate probit models}

193

The multivariate probit (MVP) model was applied in this study to assess the multivariate adoption decision in the presence of adoption interdependence. It is a generalization of the probit model used to estimate several correlated binary outcomes jointly, which considers the possible contemporaneous correlation in the decision using different practices [22]. Furthermore, the MVP model can simultaneously estimate a variety of factors that affect the application of different technologies, and the relationship between the different technologies. Crucially, the fact that the decision of adopting a certain practice may be conditional on the adoption of another complementary practice (positive correlation in the error terms of adoption equations) or may be affected by the set of substitutes that are available (negative correlation, [23]). The observed outcome of LCT adoption can be modeled using a random utility formulation. Considering that the $h^{\text {th }}$ farmer $(h=1,2,3 \ldots, \mathrm{N})$ facing a decision to use or not to use the different LCT on a plot $p(p=1,2,3, \ldots, p), U_{0}$ represents the benefit that the farmer uses traditional practices, and $\mathrm{U}_{\mathrm{j}}$ denotes the benefit of using the $j^{\text {th }} \mathrm{LCT}$ : $(\mathrm{j}=\mathrm{S}, \mathrm{T}, \mathrm{N}, \mathrm{W}, \mathrm{M}, \mathrm{F}, \mathrm{P})$ that representing the adoption of new rice varieties $(\mathrm{S})$, conservation tillage $(\mathrm{T})$, optimizing fertilizer management $(\mathrm{N})$, water-saving irrigation strategy $(\mathrm{W})$, pesticide reduction technology $(\mathrm{M})$, planting green manure in fallow winter season (F) and planting-breeding technology (P). When $Y^{*}{ }_{h p j}=\mathrm{U}_{j}-\mathrm{U}_{0}>0$, the $h^{\text {th }}$ farmer will use the $j^{\text {th }}$ LCT on plot p. Considering all LCTs, each equation in the system can be written as [Eq. (4)]:

$Y^{*}{ }_{h p j}=X_{h p j} \beta_{j}+\varepsilon_{h p j}, \quad j=\mathrm{S}, \mathrm{T}, \mathrm{N}, \mathrm{W}, \mathrm{M}, \mathrm{F}, \mathrm{P}$

where $\mathrm{Y}_{\text {hpj }}$ is a latent variable which can be represented by the level of expected benefit and/or utility derived from adoption, determined by observed household, plot and extension-related variables $\left(\mathrm{X}_{\mathrm{hpj}}\right)$ and unobserved characteristics $\left(\varepsilon_{h p j}\right), \beta_{j}$ is the corresponding vector of parameters [Eq. (5)]:

$$
Y_{\text {hpj }}=\left\{\begin{array}{cc}
1 & \text { if } Y_{\text {hp }}^{*}>0 \\
0 & \text { otherwise }
\end{array}\right.
$$

where $Y_{h p j}$ is the adoption of the $j^{\text {th }}$ LCT by the $h^{\text {th }}$ farmer on $p^{\text {th }}$ plot. In the multivariate model, where the adoption of several LCTs is possible, the error terms have a multivariate normal (MVN) distribution with zero conditional mean and covariance matrix $W$ with diagonal elements equal to unity (for identification of the parameters). The off-diagonal elements represent the unobserved correlation between the random components of the different LCTs. Thus, $\varepsilon_{h p j} \sim \mathrm{MVN}(0, W)$, and the covariance matrix $W$ is given by [Eq. (6)]: 
$W=\left[\begin{array}{ccccccc}1 & p_{s t} & p_{s w} & p_{s n} & p_{s m} & p_{s f} & p_{s p} \\ p_{t s} & 1 & p_{t w} & p_{t n} & p_{t m} & p_{t f} & p_{t p} \\ p_{w s} & p_{w t} & 1 & p_{w n} & p_{w m} & p_{w f} & p_{w p} \\ p_{n s} & p_{n t} & p_{n w} & 1 & p_{n m} & p_{n f} & p_{n p} \\ p_{m s} & p_{m t} & p_{m w} & p_{m n} & 1 & p_{m f} & p_{m p} \\ p_{f s} & p_{f t} & p_{f w} & p_{f n} & p_{f m} & 1 & p_{f p} \\ p_{p s} & p_{p t} & p_{p w} & p_{p n} & p_{p m} & p_{p f} & 1\end{array}\right]$

where $p$ (rho) denotes the pairwise correlation coefficient of the error terms corresponding to any two LCTs' adoption equations to be estimated in the model. MVP is based on seven binary dependent variables, and each takes one if the farmer uses the respective practices during interview period in the 2013 cropping season, and zero otherwise. In this model, $p$ is not just a correlation coefficient, but carries more information. A positive correlation is interpreted as a complementary relationship, while a negative correlation is interpreted as being substitutes.

\section{Results and Discussion}

\section{Count data model estimates}

\section{Level of the adoption of low carbon technologies}

The percentages of sampled farmers adopting each of the LCTs considered for the analysis are different in Table 3. LCTs are a plat form that can be used to aggregate different technologies, which widely recognized as a key approach for the reduction of GHGs emission in rice-growing countries (Sánchez et al., 2016). Our results showed that the water-saving irrigation technology was the first adopted LCT by rice farmers, followed by pesticide reduction technology and planting green manure, respectively. In contrast, very few farmers adopted planting-breeding technology and new rice varieties in paddy soil. Lastly, minimum of LCT adoption by famers (18\%) in rice production is conservation tillage. Profit-oriented farmers are more attracted to the use of water-saving irrigation technology as the use of the technology will increase their utility [15]. Instead, although conservation tillage will reduce human labor, it significantly reduces the success rate of seedling transplant, results in marked reductions in crop growth and grain yield [24]. In respect of the distribution of the number of LCTs adopted by farmers (Fig. 2), the mean number of LCTs adopted by farmers is 2.66 with a standard deviation of 1.36. The distribution of farmers' adopting LCTs showed normal distribution and slightly skewed to the left. About $30 \%$ of the farmers had adopted three LCTs, followed by choosing two LCTs in rice production. Around $18 \%$ of farmers adopted one or four kinds of LCTs, respectively. It also demonstrates that only 3 rice farmers adopt all seven practices (Fig. 2). It is easily to understand that 
farmers are quite conservative facing the choice in the adoption of a new technology, which is more

likely to adopt a mean number of new technology [15].

250

251

252

253

254

255

256

257

258

259

260

261

262

263

264

265

\section{Determinants of the intensity of low carbon technologies adoption}

A hypothesis test for over-dispersion $(\alpha=0)$ was conducted to identify the most appropriate model. The log-likelihood values yielded by unrestricted negative binomial model are similar to the restricted

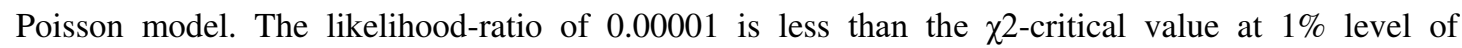
significance, which suggests the appropriateness of using the Poisson model [15]. The result of the hypothesis test was confirmed by insignificant coefficient of the dispersion parameter. Therefore the value, sign and significance of the estimated coefficients in these two models are identical to each other. Education was found to have a significant positive effect on the intensity of adoption of LCTs (Table 4). As expected, more educated and experienced farmers are in a better position to assess the relevance of new technologies $[1,25]$. In addition, farmers who have big household size adopted more LCTs due to some of the LCTs (water-saving irrigation and planting-breeding technology) are labor intensive during rice growing seasons, which is consistent with a previous study in Northeast China [1]. However, these farmer characteristics have small marginal effects on the adoption of LCTs. In particular, more risk-averse farmers tend to adopt fewer LCTs, and farmers who had higher low carbon agriculture awareness applied more LCTs in rice production. The fact that increasing the awareness of climate change would lead to increased adoption of mitigation measures is in line with many previous studies $[26,27]$. The estimated marginal effects suggest that the increasing the awareness of climate change increases the likelihood of LCTs adoption by $27 \%$. Furthermore, some of the crop practices in paddy soil such as conservation tillage, pesticide reduction technology and planting green manure require mechanical technologies for their large-scale implementation, thus it is not surprising machinery ownership significantly increased the intensity of LCTs adopted substantially. Technical support was also found to have a significant positive effect on the extent of LCTs adopted. In most cases, farmers need more technical support such as on farm demo or attendance at training to improve their capacity to apply the LCTs effectively. Thus, the availability acquirement of technical service will encourage the adoption of LCTs. These results were in consistent with the previous studies [1, 27, 28, 29]. Moreover, financial supports, like subsidies, were also presumed to be the determinants of the adoption of LCTs. Rational use of limited public budgets available for land use policies implies that subsidies are utilized 
to correct market failures, i.e. to incentivize recipients to make choices they would not do under market circumstances [30].

\section{Multivariate probit models estimates}

\section{Correlations among the adoptions of different low carbon technologies}

Under the null hypothesis of multivariate probit models, the likelihood ratio test $\left(\mathrm{chi}^{2}(10)=137.42, \mathrm{p}=\right.$ 0.00001) of the error terms are independent is strongly rejected. This statistical result shows that the error terms under the hypothesis in the LCTs adoption decision equations are correlated, and that under the MVP model is suitable in the case. Our results indicate that there is a significant relationship among LCTs, and the use of the practices is interdependent in that the probability of using a practice depends on the use of the other practices considered. It is very vital to consider an alternative character among the different LCTs. Examination of these coefficients allows for the measurements of correlation between relevant LCTs adoption decisions after the influence of observed factors has been accounted for [31]. The estimated correlation coefficients are statistically significant in five of the twenty-one cases, where two coefficients are positive and the rest three are negative. The positive signs of the correlation coefficients suggest that the decision to adopt one of the practices makes it more likely to use another practice. However, the different LCTs with negative signs of the correlation coefficients show that one of the practices has played supplementary role to another practice [15]. For instance, there is a complementary effect between conservation tillage and optimized fertilization; moreover, planting green manure and optimizing fertilizer management also appear a complementary effect. Gao et al. [32] found that long-term winter green manure incorporation significantly improved the paddy soil microbial properties and enzyme activities, which is an effective measure to improve the paddy soil health and fertility. There is a substitution effect between water-saving irrigation strategy and pesticide reduction technology, pesticide reduction technology and planting-breeding technology, planting green manure and planting-breeding technology. The interrelation of the different LCTs sheds insight to the design of implementation strategies and polices in that a policy targeted on one of the LCTs could have spillover effect on the other practices.

\section{Determinants of individual low carbon technologies adoption}

The MVP model provides a more detailed understanding of the factors influencing the adoption of 
individual LCTs in paddy field (Table 6). The hypothesis that the correlations between the error terms of the equations are all zero, and can be rejected at a high level of significance. This finding confirms that the MVP model fits the data better than the seven distinct univariate probit models (Table 6). Explanatory variables related to farmer characteristics had varied significantly across the seven dependent variables. Age of farmer was negatively associated with water-saving irrigation and planting green manure in fallow winter season. This is in line with our hypothesis that older farmers are less likely to adopt technologies which will drain physical strength largely. Higher education level was expected to encourage the adoption of complex and difficult LCTs such as conservation tillage, optimizing fertilizer management, integrated pest control technologies, planting green manure and planting combination management. The implementation of new practices is closely related to innovation of ideas and implementation by practitioners [33]. Age and education are essential determinants to innovation [34] and to agricultural innovation [33]. Abdulai et al. [35] showed that larger households had more motivation to adopt new technologies than smallerhouseholds. The results presented here also indicated that the household size had a positive significant influence on the adoption of water-saving irrigation, integrated pest control technologies and planting green manure. The additional labor demands of the technology during labor scarcity has negative effects on the adoption of LCTs. Farming households whose family members are occupied with on-farm activities have a higher probability to adopt labor-intensive technologies [36]. Furthermore, these households are able to take advantage of human capital as well as asset stocks that come with new technologies [37]. Members of a certain group are able to share information with group members, which accelerates the adoption and diffusion of technology [38].

The second set of variables examines the relationship between farmers' attitudes and adoption of technology. The increased awareness of climate change contributes to wider adoption of mitigation measures [26, 27, 39]. Our results showed that the farmers' awareness of climate change has significantly positive impacts on the adoption of all LCPs apart from new rice varieties. This fits with our prediction that farmers would be more likely to adopt LCTs if they have a strong awareness of climate change. The coefficient for "Risk aversion" was negative and significant for the farmer's decision to adopt conservation tillage measures that were consistent with Bewket et al. [40] in northwestern highlands of Ethiopia. The next set of explanatory variables is composed of field characteristics factors such as farm income ratio, farm size, machinery ownership, and soil fertility and 
irrigation status. Machinery ownership has a positive significance test in the adoption of conservation tillage and pesticide reduction technology by farmers. Soil fertility deficiency was negative significant for new rice varieties and planting green manure. Farmers with fertile plots generally realize higher returns even without much investment in management, who were reluctant to invest in relatively costly inputs like drought or disease tolerant seeds, unless the productivity impacts are substantial.

The importance of financial and technical support have been highly recognized in the promoting the adoption of LCTs. Credit accesses for farmers to adopt LCTs are characterized by positive influence at pesticide reduction technology and planting-breeding technology. This suggested that farmers' investment in the adoption of LCTs is affected by the financial institutions or government subsidies support, especially for some LCTs where a massive influx of funding is needed. However, credit-constrained households are more likely to adopt water-saving irrigation and planting green manure, both of which can be implemented by using household labor and thereby circumventing liquidity constraints. Smith et al. [41] pointed out that the economic limitations may be a huge barrier to the adoption of mitigation practices. Many researchers also found that farmers have an obvious advantages in the access to credit with larger farm sizes and capital, which determines its lower borrowing costs directly $[12,15]$. In our study, government technical service had a positive impact on the adoption of new rice varieties, through optimizing fertilizer management, water-saving irrigation and planting-breeding technology adoption by farmers. In fact, technical service for the LCTs from government has an significant positive effect on the adoption of LCTs using material objects (e.g., increasing organic fertilizer application, high-yield varieties, planting combination), while it plays an opposite role in the adoption of conservation tillage where farmers don't have an intuitive appreciation for the effect of technology adoption. Subsidies were presumed to be the determinants of adoption decisions [21]. These LCTs such as new rice varieties, conservation tillage, optimizing fertilizer management, pesticide reduction technology and planting green manure adoption by rice farmers have receives direct or indirect subsidies in HP. The practices such as planting-breeding technology that do not receive subsidies may require a higher level of private investment and therefore their implementation relies only on the possible economic benefit for the farmer.

\section{Conclusions and implications}



various adaptation strategies to cope with global warming and increased extreme climate events in rice production. Water-saving irrigation, pesticide reduction technology and planting green manure in fallow winter season were the major adaptation strategies adopted by farmers in HP. In addition, our results indicated that the factors influencing farmers' adoption of LCTs are mainly affected by education, climate change awareness, household size, technical support and subsidies. Furthermore, farmers' use of optimizing fertilizer management were packaged together with conservation tillage and planting green manure in fallow winter season. The substitution effect between integrated pest management techniques and planting-breeding technology adaption by famers can be found in HP. The main sociodemographic determinant which affected farmers' likelihood of adoption is the education level of farmers. The government extension service is an important factor that influences household's adoption of LCTs that demand external knowledge and/or inputs. The government's propaganda and support for LCTs are not strong enough although the government highlights the significance and necessity of climate change awareness. It is not enough to guide farmers to make technology choices. Technology subsidies for agriculture is important for their ability to deliver as an effective policy of technology adoption to climate change. These results would yield implications to help policy makers to design appropriate entry strategy to promote the use of LCTs. It is inappropriate to assert that smallholder farmers are reluctant to accept LCTs since different LCTs would require different entry points and promotion strategies. The result of the present study reveals that there is a significant correlation between the adoption of different LCTs and the use of the practices, which depicts either complementation or substitution among these practices. The potential correlation between the unobserved disturbances in the decision equations and the use of different practices could be ignored in

391 The government should comprehensively consider the alternative and complementary effect of the farmer adoption decision in the agricultural technology promotion, and continue to improve the agricultural technology popularization system and strengthen the technical guidance such as implementation of the lecture field observation and field experiments. Meanwhile, we should also pay attention to the cooperative adoption of variousfarming technologies which exit a complementary relationship, and for the low carbon technology which exit substitutional relation, we need to consider 
actual circumstances, take measures to diapel the prejudice to the technology adoption, and encourage farmers to actively adopt various LCTs. Finally, a follow-up survey that screens out the adoption variables over time will enable researchers to conduct similar studies using a panel data set. This provides a more comprehensive analysis of farmers' long-term adoption of new technologies.

\section{Abbreviations}

HP: Hunan Province; LCTs: Low carbon technologies; GHGs: greenhouse gases; CH4: methane; N2O: nitrous oxide; MVP: multivariate probit; S: new rice varieties; T: conservation tillage; N: optimizing fertilizer management; W: water-saving irrigation strategy; M: pesticide reduction technology; F: planting green manure in fallow winter season; P: planting-breeding technology; MVN: multivariate normal

\section{Funding}

This study was supported by the Project of National Key Research and Development Program of China (2016YFD0300210).

\section{Acknowledgements}

We would like to express our sincere thanks to Heshui Xu, Dengyun Li, Wenguang Tang, Haiming Tang, Yong li, Shengli liu, Ge Xu for providing support in field survey in Hunan Province of China. We also greatly thank Heshui Xu, Zhe Zhu and Changliang Shi for their suggestions in statistics analyses.

\section{Authors' contributions}

Zhongdu Chen collected and analysed the data. Fu Chen discussed the results. All authors assisted in writing the manuscript. All authors read and approved the final manuscript

\section{Availability of data and materials}

The dataset supporting the conclusions of this article is included within the article.

\section{Ethics approval and consent to participate}

Not applicable.

\section{Consent for publication}

Not applicable.

\section{Competing interests}

The authors declare that they have no competing interests

\section{References}

1. Yin XG, Olesen JE, Wang M, Öztürk I, Chen F. Climate effects on crop yields in the Northeast Farming Region of China during 1961-2010. J Agr Sci. 2016b; 154: 1190-1208.

2. Howden SM, Soussana JF, Tubiello FN, Chhetri N, Dunlop M, Meinke H. Adapting Agriculture to Climate Change. PNAS. 2007; 104:19691. 
3. Mccarl BA. Analysis of climate change implications for agriculture and forestry: an interdisciplinary effort. Climatic Change. 2010; 100:119-124.

4. Shang QY, Yang XX, Gao CM, Wu PP, Liu JJ, Xu YC, Shen QR, Zou JW, Guo SW. Net annual global warming potential and greenhouse gas intensity in Chinese double rice-cropping systems: a 3-year field measurement in long-term fertilizer experiments. Global Change Biol. 2011; 17: 2196-2210.

434 5. Coumou D, Rahmstorf S. A decade of weather extremes. Nat Clim Change. 2012; 2: 491-496.

435 6. FAO statistical databases. Rome: FAO; 2013 [http://faostat.fao.org; verified Feb, 2014].

436 7. Liu SL, Xue JF, Zhang R. Sensitivity analysis of double-rice yield under climate change in Hunan Province. TCSAE. 2015; 6: 246-252. (in Chinese)

8. NPC (The National People's Congress, P.R. China), 2011. The Twelfth Five-year Plan for National Economic and Social Development of People's Republic of China. The National People's Congress, Beijing.

10. Chen Z D, Dikgwatlhe SB , Xue JF. Tillage impacts on net carbon flux in paddy soil of the Southern China. J Clean Prod, 2015, 103:70-76

11. Xu Y, Ge JZ, Tian SY, Li SY, Nguy-Robertson AL, Zhan M, Cao CG. Effects of water-saving irrigation practices and drought

12. Kassie M, Jaleta M, Shiferaw B, Mmbando F, Mekuria M. Adoption of interrelated sustainable agricultural practices in smallholder systems: Evidence from rural Tanzania. Technological Forecasting \& Social Change. 2013; 80: 525-540.

13. Caswell M F. Adoption of agricultural production practices. 2001.

14. Boyd C. Turton C. The contribution of soil and water conservation to sustainable livelihoods in semi-arid areas of sub-Saharan Africa. Herzschrittmachertherapie + Elektrophysiologie. 2000. 17, 80-86.

15. Mariano M J, Villano R, Fleming E. Factors influencing farmers' adoption of modern rice technologies and good management practices in the Philippines. Agr Syst. 2012; 110: 41-53.

16. Sánchez B, Álvaro-Fuentes J, Cunningham R, Iglesias A. Towards mitigation of greenhouse gases by small changes in farming practices: understanding local barriers in Spain. Mitig Adapt Strat Gl. 2014.

17. Kim S, Gillespie J M , Paudel K P. The effect of socioeconomic factors on the adoption of best management practices in beef cattle production. General Information. 2005; 60(3):111-120.

18. Rahelizatovo N C, Gillespie J M. The Adoption of Best-Management Practices by Louisiana Dairy Producers. J Agr Appl Eco. 2004; 36: 229-240.

19. Shiferaw B, Obare G, Muricho G, Silim S. Leveraging institutions for collective action to improve markets for smallholder producers in less-favored areas. Africa J Agr Res Eco. 2009; 03. Northeast Farming Region of China. Eur J Agron. 2016a; 77: 47-58.

21. Mi S H, Huang Z H, Zhu Q B. Study on factors influencing farmers'adoption of low-carbon technologies. Acta Agriculturae 
22. Gillespie J M, Davis C G, Rahelizatovo N C. Factors Influencing the Adoption of Breeding Technologies in U.S. Hog Production. J Agr Appl Eco. 2004; 36: 35-47.

23. Khanna M. Sequential Adoption of Site-Specific Technologies and Its Implications for Nitrogen Productivity: A Double Selectivity Model. Am J Agr Econ. 2001; 83: 35-51.

24. Al-Kaisi M M, Yin X. Tillage and crop residue effects on soil carbon and carbon dioxide emission in corn-soybean rotations. Journal of Environmental Quality, 2005; 34: 437-445.

25. Chander P, Thangavelu S M. Technology adoption, education and immigration policy. J Devel Eco. 2004; 75: $79-94$.

26. Prokopy L S, Floress K, Klotthor-Weinkauf D, Baumgart-Getz A. Determinants of agricultural best management practice adoption: Evidence from the literature. Journal of Soil Water Conserv. 2008; 63: 300-311.

27. Tambo J A, Abdoulaye T. Climate change and agricultural technology adoption: the case of drought tolerant maize in rural Nigeria. Mitigation \& Adaptation Strategies for Global Change. 2012; 17: 277-292.

28. Cary J, Webb T, Barr N. The adoption of sustainable practices: Some new insights. An analysis of drivers and constraints for the adoption of sustainable practices derived from research. 2001.

29. Prager K, Posthumus H. Socio-economic factors influencing farmers' adoption of soil conservation practices in Europe. Nova Science Publishers Inc. 2010.

30. Kotecký V. Contribution of afforestation subsidies policy to climate change adaptation in the Czech Republic. Land Use Policy. 2015. 47, 112-120.

31. Greene W H. Econometric analysis. Contributions to Management Science. 2002; 89: 182-197.

32. Gao S J, Cao, W D, Bai J S. long-term application of winter green manures changed the soil microbial biomass properties in red paddy soil. Acta Pedologica Sinica. 2015; 52: 902-910. (in Chinese)

34. Clinton A, House J H. Attributes of Innovations as Factors in Diffusion. Adoption. 1970; 32.

36. Moser C M, Barrett C B. The disappointing adoption dynamics of a yield-increasing, low external-input technology: the

37. Parthasarathy D, Chopde V K. Building social capital: collective action, adoption of agricultural innovations, and poverty reduction in the Indian semi-arid tropics, Paper Prepared for Global Development Network. 2000.

38. Munasib A B A, Jordan J L. The Effect of Social Capital on the Choice to Use Sustainable Agricultural Practices. J Agr Appl Eco. 2011; 43: 213-227.

39. Jalón S G D, Iglesias A, Quiroga S, Bardají I. Exploring public support for climate change adaptation policies in the Mediterranean region: A case study in Southern Spain. Environ Sci Policy. 2013; 29: 1-11. 

agriculture. Phil Trans R Soc B. 2008; 363(1492):789-813.

\section{3}

504 


\section{$505 \quad$ Figure captions}

506 Fig. 1 Map showing the location and distribution of the sampled holdings. A shows the location of

507 Hunan in China. B further divides the region into its eight counties, from north to south, Changde,

508 Yiyang, Yueyang, Changsha, Zhuzhou, Shaoyang, Hengyang and Chenzhou.

509 Fig. 2 Distribution of total LCTs adopted by rice farmers in Hunan province

510 
Tables captions

Table 1

Detailed description of the seven selected low carbon technologies for this case study

\begin{tabular}{|c|c|c|c|}
\hline $\begin{array}{l}\text { Low carbon } \\
\text { technologies }\end{array}$ & Description of the LCTs & $\begin{array}{l}\text { Potential emission } \\
\text { reduction rate }\end{array}$ & Sources \\
\hline New rice varieties & $\begin{array}{l}\text { Rice varieties, such as pest-resistant } \\
\text { genetically modified varieties, } \\
\text { efficient use of nitrogen fertilizer } \\
\text { varieties, which can reduce the use of } \\
\text { pesticides and nitrogen inputs or } \\
\text { increase rice yield, or improve their } \\
\text { oxidation in rhizosphere and } \\
\text { transmission capacity, finally } \\
\text { markedly reduce } \mathrm{CH}_{4} \text { emissions. }\end{array}$ & $0.51-1.39$ t CO$_{2}$-eq ha ${ }^{-1}$ & $\begin{array}{l}\text { Tao, 2008; Fu } \\
\text { et al., 2010; } \\
\text { Xu et al.2015 }\end{array}$ \\
\hline $\begin{array}{l}\text { Conservation } \\
\text { tillage }\end{array}$ & $\begin{array}{l}\text { Reducing or avoiding tillage } \\
\text { practices, which can increase soil } \\
\text { carbon storage through reducing } \\
\text { microbial decomposition, and } \\
\text { promoting crop residue incorporation } \\
\text { into soil. }\end{array}$ & $0.23-0.71 \mathrm{t} \mathrm{CO}_{2}$-eq ha ${ }^{-1}$ & $\begin{array}{l}\text { Zhang et al., } \\
\text { 2013; Chen et } \\
\text { al., 2014; Xue } \\
\text { et al., } 2014\end{array}$ \\
\hline $\begin{array}{l}\text { Optimizing } \\
\text { fertilizer } \\
\text { management }\end{array}$ & $\begin{array}{l}\text { Changes of fertilizer application rates, } \\
\text { for instance, applying fertilizer } \\
\text { depending on crop needs in different } \\
\text { rice growth phases in order to } \\
\text { increase fertilizer use efficiency thus } \\
\text { reducing GHG emissions, especially } \\
\text { nitrous oxide. }\end{array}$ & $0.36-0.62 \mathrm{t} \mathrm{CO}_{2}$-eq ha ${ }^{-1}$ & $\begin{array}{l}\text { Snyder et al., } \\
\text { 2010; Shang et } \\
\text { al., 2012; Chen } \\
\text { et al., } 2016\end{array}$ \\
\hline $\begin{array}{l}\text { Water-saving } \\
\text { irrigation strategy }\end{array}$ & $\begin{array}{l}\text { This practice usually comprises one } \\
\text { or several drainage periods in paddy } \\
\text { soil, which prevents the development } \\
\text { of soil reductive conditions and } \\
\text { markedly reduces } \mathrm{CH}_{4} \text { emissions. }\end{array}$ & $0.38-1.29 \mathrm{t} \mathrm{CO}_{2}$-eq ha ${ }^{-1}$ & $\begin{array}{l}\text { Ahn et al., } \\
\text { 2014; Win et } \\
\text { al., 2015; Xu } \\
\text { et al., } 2015\end{array}$ \\
\hline $\begin{array}{l}\text { Pesticide } \\
\text { reduction } \\
\text { technology }\end{array}$ & $\begin{array}{l}\text { It consists of reduced herbicide, hand } \\
\text { weeding or pest control with light trap } \\
\text { in order to reduce the pesticide inputs, } \\
\text { thus reducing GHG emissions. }\end{array}$ & $0.48-1.85 \mathrm{t} \mathrm{CO}_{2}$-eq ha ${ }^{-1}$ & $\begin{array}{l}\text { Lei, 2013; } \\
\text { Chen et al., } \\
2016 \text {; } \\
\text { Zhang et al., } \\
2016\end{array}$ \\
\hline $\begin{array}{l}\text { Planting green } \\
\text { manure in fallow } \\
\text { winter season }\end{array}$ & $\begin{array}{l}\text { Planting green manure in the winter } \\
\text { fallow field, increases soil carbon } \\
\text { stores and reduced fertilizer use, } \\
\text { thereby reducing nitrous oxide } \\
\text { emissions. }\end{array}$ & $0.12-1.87 \mathrm{t} \mathrm{CO}_{2}$-eq ha ${ }^{-1}$ & $\begin{array}{l}\text { Xu et al., } \\
\text { 2016; Shang et } \\
\text { al., 2016; } \\
\text { Wang et al., } \\
2015\end{array}$ \\
\hline $\begin{array}{l}\text { Planting-breeding } \\
\text { technology }\end{array}$ & $\begin{array}{l}\text { Common cultivation aquaculture in } \\
\text { paddy fields, aerate the paddy soil by } \\
\text { burrowing into the soil for searching } \\
\text { food, prevent a drop in the redox } \\
\text { potential and lower } \mathrm{CH}_{4} \text { emission }\end{array}$ & $0.78-2.12$ t CO$_{2}$-eq ha ${ }^{-1}$ & $\begin{array}{l}\text { Datta et al., } \\
2009 ; \\
\text { Bhattacharyya } \\
\text { et al., 2013; } \\
\text { Xu et al., } 2017\end{array}$ \\
\hline
\end{tabular}




\begin{tabular}{|c|c|c|c|c|}
\hline Variable & Description & $\begin{array}{l}\text { Expected } \\
\text { sign }\end{array}$ & Mean & SE \\
\hline \multicolumn{5}{|l|}{ Dependent variable } \\
\hline New rice varieties & Practice is implemented $(1=$ yes, $0=$ no or not sure $)$ & & 0.28 & 0.45 \\
\hline Conservation tillage & Practice is implemented $(1=$ yes, $0=$ no or not sure $)$ & & 0.17 & 0.38 \\
\hline Optimizing fertilizer management & Practice is implemented ( $1=$ yes, $0=$ no or not sure $)$ & & 0.37 & 0.48 \\
\hline Water-saving irrigation & Practice is implemented $(1=$ yes, $0=$ no or not sure $)$ & & 0.57 & 0.49 \\
\hline Pesticide reduction technology & Practice is implemented $(1=$ yes, $0=$ no or not sure $)$ & & 0.50 & 0.50 \\
\hline Planting green manure in winter season & Practice is implemented $(1=$ yes, $0=$ no or not sure $)$ & & 0.46 & 0.50 \\
\hline Planting-breeding technology & Practice is implemented ( $1=$ yes, $0=$ no or not sure $)$ & & 0.31 & 0.46 \\
\hline Low carbon technologies & Adoption intensity of low carbon technologies (taking on values from 0 to 7 ) & & 2.66 & 1.36 \\
\hline \multicolumn{5}{|l|}{ Independent Variable } \\
\hline \multicolumn{5}{|l|}{ Farmer characteristics } \\
\hline Gender & 1 if the farmer is male; 0 otherwise & + & 0.91 & 0.29 \\
\hline Age & Age of the farmers (years) & $+/-$ & 49.74 & 8.81 \\
\hline Education & $\begin{array}{l}\text { Farmer having a formal education (no=0, primary school=6, junior high school=9, senior high } \\
\text { school }=12 \text {, university }=16 \text { ) }\end{array}$ & + & 6.39 & 4.01 \\
\hline Experience & Years of rice farming experience of the farmer & + & 18.86 & 10.54 \\
\hline Household size & Number of family members & + & 4.34 & 1.26 \\
\hline \multicolumn{5}{|l|}{ Farmer behavior } \\
\hline Climate change awareness & 1 if the farmer realize climate change ; 0 otherwise & + & 0.47 & 0.50 \\
\hline Low carbon agriculture awareness & 1 if the farmer realize low carbon agriculture ; 0 otherwise & + & 0.33 & 0.47 \\
\hline Risk aversion & 1 if the farmer practices crop diversification; 0 otherwise & + & 0.35 & 0.48 \\
\hline \multicolumn{5}{|l|}{ Field characteristics } \\
\hline Farm income ratio & $\begin{array}{l}\text { Income ratio from rice farming of total income }(1=0-24 \% ; 2=25-49 \% ; 3=50-74 \% \text {; } \\
4=75-100 \%)\end{array}$ & - & 2.41 & 1.12 \\
\hline Farm size & Total rice area planted in hectares & + & 3.99 & 2.47 \\
\hline Machinery ownership & 1 if the farmer owns any tractor or harvester; 0 otherwise & + & 0.37 & 0.48 \\
\hline Soil fertility deficiency & 1 if the farmer's field is nutrient deficient; 0 otherwise & - & 0.61 & 0.49 \\
\hline Sufficient water irrigation & 1 if the farmer has an adequate source of water for irrigation; 0 otherwise & + & 0.66 & 0.47 \\
\hline \multicolumn{5}{|l|}{ External environment } \\
\hline Credit access & 1 if the farmer has access to credit; 0 otherwise & + & 0.44 & 0.50 \\
\hline Technical support & 1 if the farmer get technical support; 0 otherwise & + & 0.33 & 0.47 \\
\hline Subsidies & 1 if farm subsidy received by implementing mitigation practices; 0 otherwise & + & 0.61 & 0.49 \\
\hline
\end{tabular}


Table 3

519 Adoption of the low carbon technologies in rice production in Hunan Province

\begin{tabular}{lll}
\hline Low carbon technologies & Numbers & Percentage (\%) \\
\hline LCT1. New rice varieties & 153 & 27.6 \\
LCT2. Conservation tillage & 97 & 17.5 \\
LCT3. Optimizing fertilizer management & 253 & 45.6 \\
LCT4. Water-saving irrigation & 319 & 57.5 \\
LCT5. Pesticide reduction technology & 203 & 36.6 \\
LCT6. Planting green manure in fallow winter season & 277 & 49.9 \\
LCT7. Planting-breeding technology & 173 & 31.2 \\
\hline
\end{tabular}


Table 4

522 Coefficient estimates and marginal effects of the Poisson regression model.

\begin{tabular}{|c|c|c|c|c|}
\hline \multirow{2}{*}{ Variable } & \multicolumn{2}{|c|}{ Coefficient estimates } & \multicolumn{2}{|c|}{ Marginal effects } \\
\hline & Coef. & Std. error & Coef. & Std. error \\
\hline \multicolumn{5}{|c|}{ Dependent variable: (number of LCTs adopted) } \\
\hline \multicolumn{5}{|c|}{ Farmer and household characteristics } \\
\hline Gender & 0.0848 & 0.0720 & 0.2110 & 0.1787 \\
\hline Age & -0.0180 & $0.0053^{c}$ & -0.0448 & $0.0131^{\mathrm{c}}$ \\
\hline Education & 0.0566 & $0.0175^{\mathrm{c}}$ & 0.1409 & $0.0186^{\mathrm{c}}$ \\
\hline Experience & 0.0075 & 0.0055 & 0.0187 & 0.0137 \\
\hline Household size & 0.0705 & $0.0396^{\mathrm{a}}$ & 0.1754 & $0.0988^{\mathrm{a}}$ \\
\hline \multicolumn{5}{|l|}{ Farmer behavior } \\
\hline Climate change awareness & 0.1109 & $0.0500^{\mathrm{b}}$ & 0.2760 & $0.1250^{\mathrm{b}}$ \\
\hline Low carbon agriculture awareness & 0.0868 & 0.0306 & 0.2161 & 0.0758 \\
\hline Risk aversion & -0.0264 & $0.0157^{\mathrm{a}}$ & -0.0657 & $0.0391^{\mathrm{a}}$ \\
\hline \multicolumn{5}{|l|}{ Field characteristics } \\
\hline Farm income ratio & -0.0327 & 0.0309 & -0.0814 & 0.0769 \\
\hline Farm size & -0.0009 & 0.0127 & -0.0023 & 0.0317 \\
\hline Machinery ownership & 0.0505 & $0.0160^{c}$ & 0.1258 & $0.0442^{\mathrm{c}}$ \\
\hline Soil fertility deficiency & -0.0398 & $0.0227^{\mathrm{a}}$ & -0.0991 & $0.0567^{\mathrm{a}}$ \\
\hline Sufficient water irrigation & 0.0672 & 0.0465 & 0.1671 & 0.1153 \\
\hline \multicolumn{5}{|l|}{ External environment } \\
\hline Credit access & 0.0184 & $0.0058^{c}$ & 0.0459 & $0.0137^{\mathrm{c}}$ \\
\hline Technical support & 0.0590 & $0.0187^{\mathrm{c}}$ & 0.1467 & $0.0414^{\mathrm{c}}$ \\
\hline Subsidies & 0.0110 & $0.0033^{c}$ & 0.0274 & $0.0075^{\mathrm{c}}$ \\
\hline Constant & 1.5385 & $0.4032^{\mathrm{c}}$ & & \\
\hline Log likelihood & -829.021 & & & \\
\hline Prob. > chi2 & 0.00001 & & & \\
\hline Pseudo $\mathrm{R}^{2}$ & 0.1419 & & & \\
\hline
\end{tabular}


Table 5

525 Correlation coefficients of LCT decisions: MVP model result

\begin{tabular}{lllllll}
\hline & $\mathrm{S}^{1}$ & $\mathrm{~T}$ & $\mathrm{~N}$ & $\mathrm{~W}$ & $\mathrm{M}$ & $\mathrm{F}$ \\
\hline $\mathrm{S}$ & & & & & \\
$\mathrm{T}$ & $-0.118(0.091)$ & & & & \\
$\mathrm{N}$ & $0.066(0.089)$ & $0.002(0.092)^{\mathrm{c}}$ & & & & \\
$\mathrm{W}$ & $0.248(0.082)$ & $-0.086(0.083)$ & $-0.205(0.081)$ & & & \\
$\mathrm{M}$ & $0.005(0.088)$ & $0.085(0.085)$ & $-0.014(0.084)$ & $-0.109(0.061)^{\mathrm{a}}$ & & \\
$\mathrm{F}$ & $-0.129(0.085)$ & $-0.111(0.081)$ & $0.065(0.080)^{\mathrm{c}}$ & $-0.063(0.076)$ & $-0.299(0.272)$ & \\
$\mathrm{P}$ & $-0.042(0.089)$ & $-0.199(0.080)$ & $-0.134(0.112)$ & $-0.258(0.280)$ & $-0.170(0.079)^{\mathrm{b}}$ & $-0.323(0.078)^{\mathrm{c}}$ \\
\hline
\end{tabular}

$\begin{array}{ll}\text { chi }^{2}(21) & 137.419 \\ \text { Prob. } & 0.00001\end{array}$

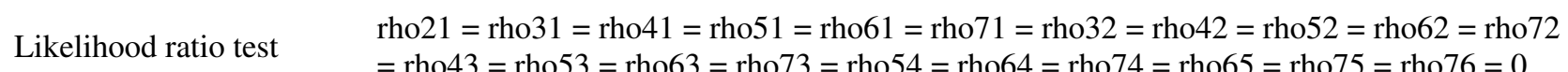

$$
=\operatorname{rho} 43=\operatorname{rho} 53=\operatorname{rho63}=\operatorname{rho} 73=\text { rho5 }=\text { rho6 } 4=\operatorname{rho} 74=\operatorname{rho} 65=\operatorname{rho} 75=\operatorname{rho} 76=0
$$

S, T, N, W, M, F and P represent new rice varieties, conservation tillage, water-saving irrigation, optimizing fertilizer management, pesticide reduction technology, planting green manure in fallow winter season, and planting-breeding technology, respectively. The figure in bracket is standard deviation.

$\left({ }^{c}\right)$ indicates pearson correlation is significant at $\mathrm{P}<0.01$ level, $\left({ }^{b}\right)$ indicates pearson correlation is significant at $\mathrm{P}<0.05$ level, ( ${ }^{\mathrm{a}}$ ) indicates pearson correlation is significant at $\mathrm{P}<0.1$ level. 
Table 6

533 Multivariate probit results on the type of low carbon technology adoption

\begin{tabular}{|c|c|c|c|c|c|c|c|}
\hline \multirow{2}{*}{ Explanatory variables } & \multicolumn{7}{|c|}{ Dependent variables } \\
\hline & $\mathrm{S}$ & $\mathrm{T}$ & $\mathrm{N}$ & $\mathrm{W}$ & M & $\mathrm{F}$ & $\mathrm{P}$ \\
\hline \multicolumn{8}{|l|}{ Farmer and household characteristics } \\
\hline Gender & $0.280(0.280)$ & $0.268(0.278)$ & $0.245(0.250)$ & $0.014(0.230)$ & $0.223(0.231)$ & $0.036(0.231)$ & $-0.013(0.250)$ \\
\hline Age & $-0.049(0.018)$ & $-0.022(0.019)$ & $0.013(0.017)$ & $-0.040(0.017)^{\mathrm{b}}$ & $-0.007(0.017)$ & $-0.037(0.017)^{\mathrm{b}}$ & $-0.026(0.017)$ \\
\hline Education & $-0.035(0.029)$ & $0.113(0.033)^{\mathrm{c}}$ & $0.050(0.028)^{\mathrm{a}}$ & $0.039(0.017)^{b}$ & $0.140(0.029)^{\mathrm{c}}$ & $0.052(0.028)^{\mathrm{a}}$ & $0.058(0.031)^{\mathrm{a}}$ \\
\hline Experience & $0.028(0.020)$ & $-0.020(0.021)$ & $-0.010(0.019)$ & $0.129(0.177)$ & $-0.016(0.019)$ & $0.034(0.018)$ & $0.038(0.019)$ \\
\hline Household size & $0.145(0.155)$ & $-0.208(0.159)$ & $0.222(0.149)$ & $0.448(0.146)^{\mathrm{c}}$ & $0.369(0.153)^{\mathrm{b}}$ & $0.256(0.144)^{\mathrm{a}}$ & $0.103(0.153)$ \\
\hline \multicolumn{8}{|l|}{ Farmer behavior } \\
\hline Climate change awareness & $0.395(0.205)$ & $0.261(0.109)^{\mathrm{a}}$ & $0.512(0.197)^{\mathrm{a}}$ & $0.395(0.118)^{\mathrm{c}}$ & $0.223(0.115)^{\mathrm{a}}$ & $0.347(0.203)^{\mathrm{a}}$ & $0.639(0.205)^{\mathrm{c}}$ \\
\hline Low carbon agriculture awareness & $0.258(0.141)^{\mathrm{a}}$ & $0.424(0.135)^{\mathrm{c}}$ & $0.042(0.033)$ & $0.186(0.130)$ & $0.016(0.019)$ & $0.195(0.125)$ & $0.237(0.139)^{\mathrm{a}}$ \\
\hline Risk aversion & $0.057(0.058)$ & $-0.096(0.026)^{\mathrm{c}}$ & $-0.056(0.058)$ & $-0.076(0.054)$ & $-0.069(0.066)$ & $0.026(0.056)$ & $-0.008(0.060)$ \\
\hline \multicolumn{8}{|l|}{ Field characteristics } \\
\hline Farm income ratio & $-0.090(0.076)$ & $0.219(0.143)$ & $0.171(0.140)$ & $0.032(0.119)$ & $-0.130(0.127)$ & $-0.169(0.131)$ & $-0.172(0.139)$ \\
\hline Farm size & $0.055(0.047)$ & $-0.062(0.055)$ & $-0.063(0.045)$ & $0.015(0.043)$ & $-0.073(0.045)$ & $-0.007(0.042)$ & $-0.001(0.045)$ \\
\hline Machinery ownership & $-0.066(0.058)$ & $0.710(0.200)^{\mathrm{c}}$ & $0.147(0.175)$ & $-0.161(0.174)$ & $-0.518(0.179)^{\mathrm{c}}$ & $-0.113(0.169)$ & $0.765(0.171)$ \\
\hline Soil fertility deficiency & $-0.193(0.102)^{\mathrm{a}}$ & $-0.098(0.077)$ & $0.153(0.087)^{\mathrm{a}}$ & $-0.031(0.089)$ & $0.046(0.092)$ & $-0.180(0.087)^{\mathrm{b}}$ & $0.020(0.090)$ \\
\hline Sufficient water irrigation & $-0.030(0.025)$ & $0.243(0.072)^{\mathrm{c}}$ & $0.109(0.156)$ & $-0.388(0.155)^{\mathrm{b}}$ & $0.356(0.163)^{\mathrm{b}}$ & $0.044(0.151)$ & $-0.095(0.161)$ \\
\hline \multicolumn{8}{|l|}{ External environment } \\
\hline Credit access & $0.075(0.066)$ & $-0.081(0.070)$ & $-0.008(0.061)$ & $-0.097(0.060)$ & $0.219(0.062)^{\mathrm{c}}$ & $-0.030(0.059)^{\mathrm{b}}$ & $0.144(0.065)^{\mathrm{b}}$ \\
\hline Technical support & $0.425(0.113)^{\mathrm{c}}$ & $-0.264(0.073)^{\mathrm{c}}$ & $0.382(0.158)^{\mathrm{b}}$ & $0.366(0.157)^{\mathrm{b}}$ & $0.145(0.166)$ & $0.064(0.153)$ & $0.377(0.164)^{b}$ \\
\hline Subsidies & $0.067(0.021)^{\mathrm{c}}$ & $0.072(0.022)^{\mathrm{c}}$ & $0.072(0.020)^{\mathrm{c}}$ & $0.009(0.018)$ & $0.069(0.020)^{\mathrm{c}}$ & $0.043(0.019)^{\mathrm{a}}$ & $0.019(0.029)$ \\
\hline Constant & $2.077(1.074)^{\mathrm{a}}$ & $-1.073(1.060)$ & $-0.978(0.910)$ & $0.969(0.976)$ & $-1.134(1.011)$ & $1.792(0.984)$ & $1.317(1.007)$ \\
\hline Log likelihood & -2034.61 & & & & & & \\
\hline Prob. $>$ chi $^{2}$ & 0.0000 & & & & & & \\
\hline Wald chi ${ }^{2}(112)$ & 1165.23 & & & & & & \\
\hline
\end{tabular}

S, T, N, W, M, F and P represent new rice varieties, conservation tillage, water-saving irrigation, optimizing fertilizer management, pesticide reduction technology, planting green manure in fallow winter season, and planting-breeding technology, respectively.

The figure in bracket is standard deviation.

${ }^{(c)}$ ) indicates pearson correlation is significant at $\mathrm{P}<0.01$ level, $\left({ }^{b}\right)$ indicates pearson correlation is significant at $\mathrm{P}<0.05$ level, $\left({ }^{\mathrm{a}}\right)$ indicates pearson correlation is significant at $\mathrm{P}<0.1$ level. 


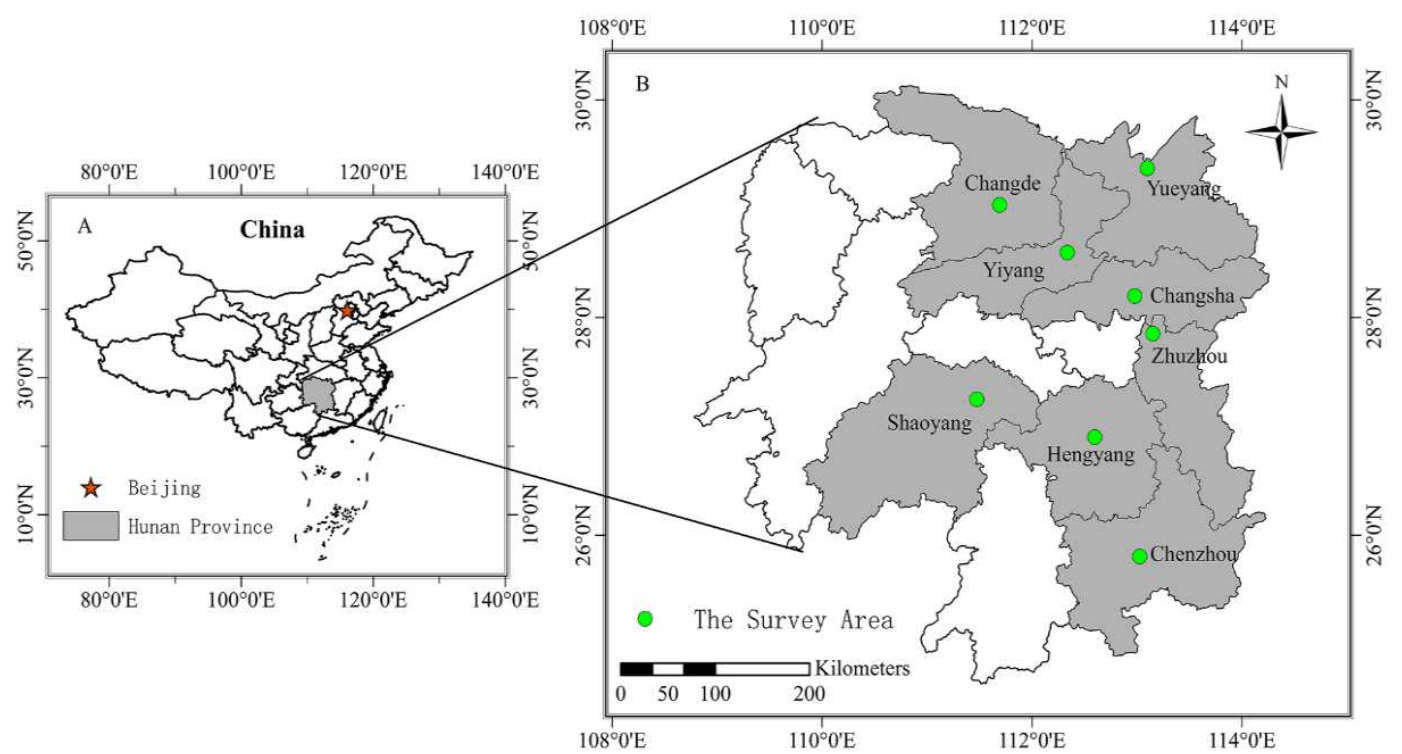

$540 \quad$ Fig. 1 


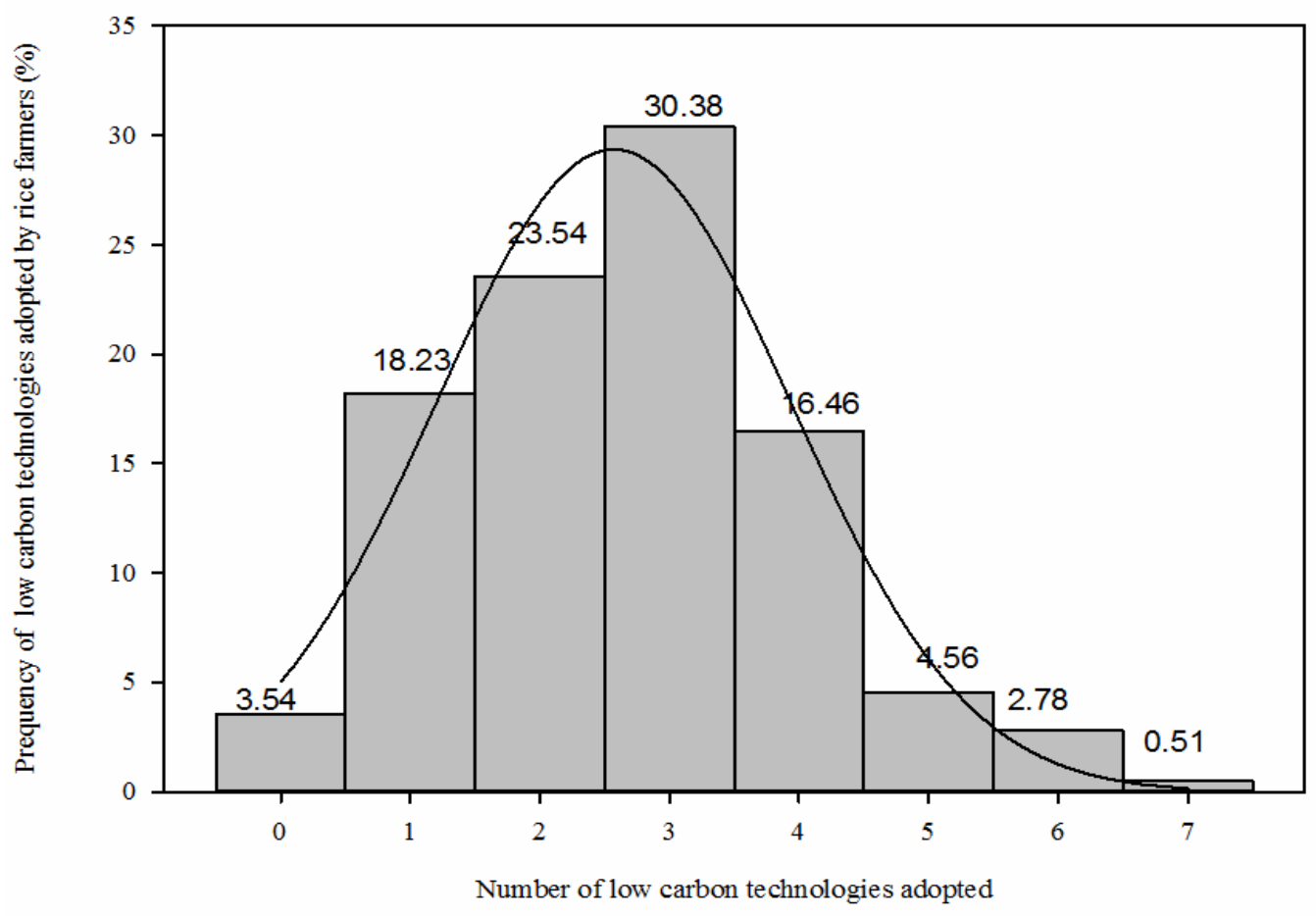

541

542 Fig. 2 


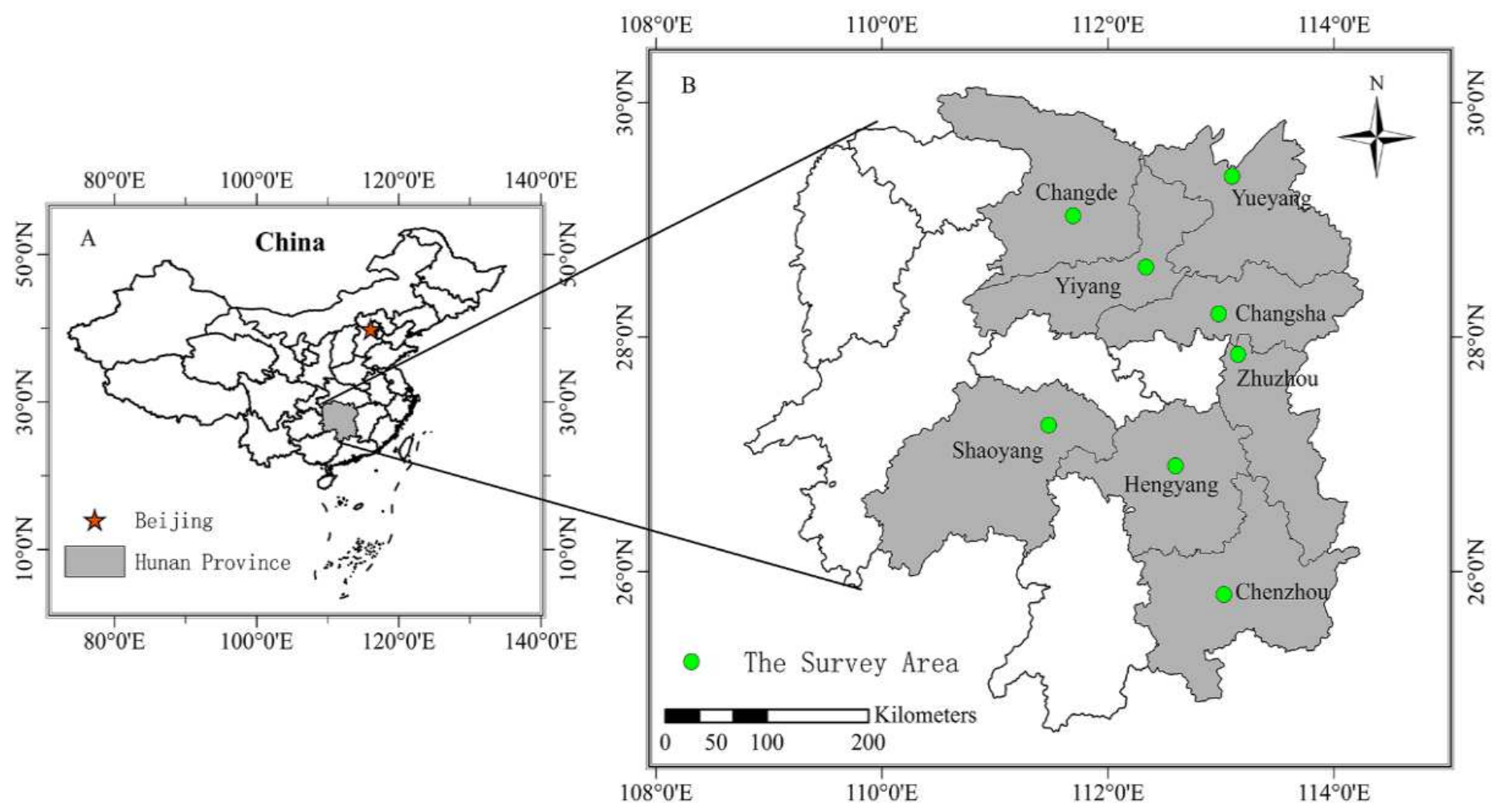

Figure 1

Map showing the location and distribution of the sampled holdings. A shows the location of Hunan in China. B further divides the region into its eight counties, from north to south, Changde, Yiyang, Yueyang, Changsha, Zhuzhou, Shaoyang, Hengyang and Chenzhou. Note: The designations employed and the presentation of the material on this map do not imply the expression of any opinion whatsoever on the part of Research Square concerning the legal status of any country, territory, city or area or of its authorities, or concerning the delimitation of its frontiers or boundaries. This map has been provided by the authors. 


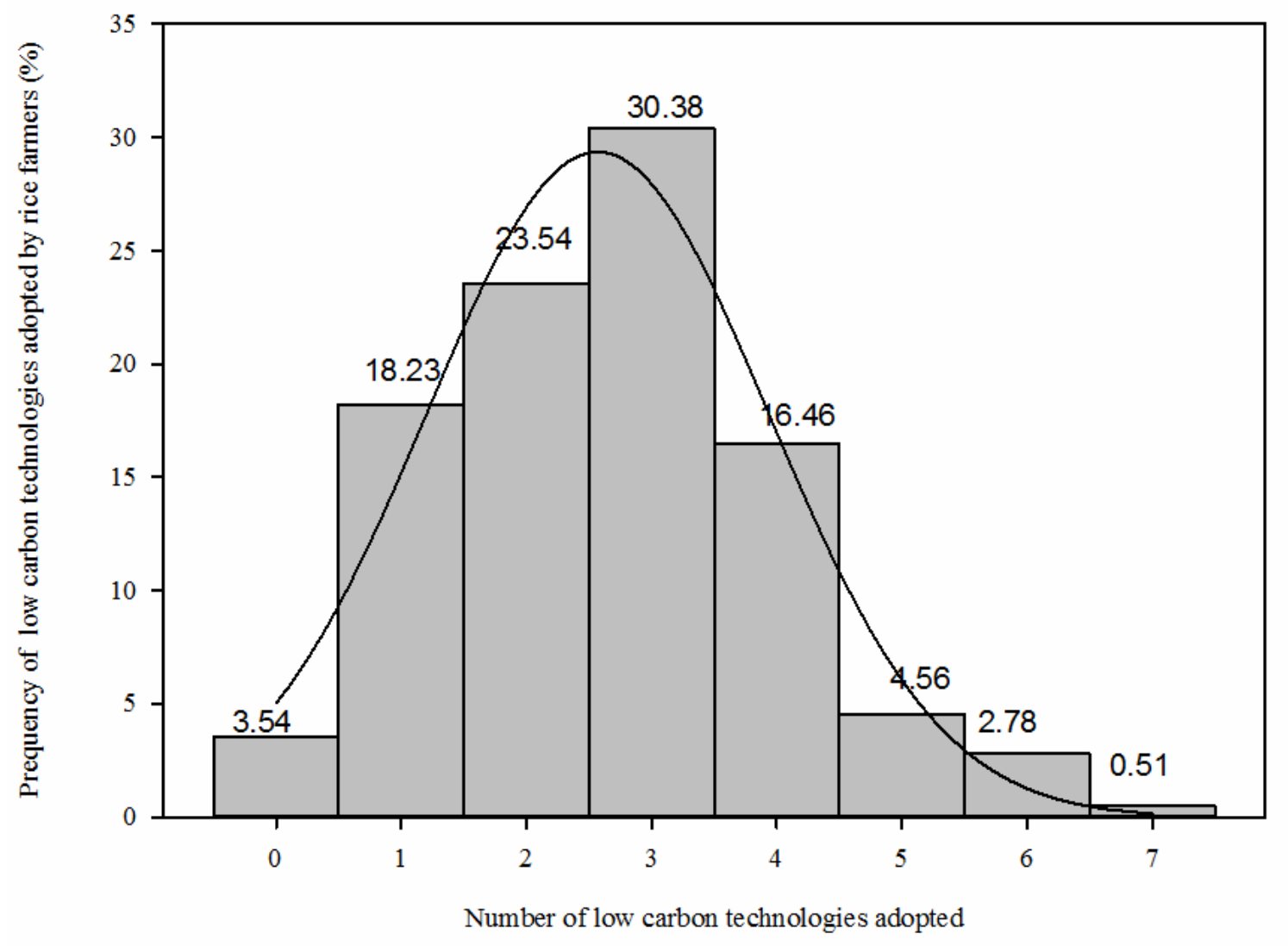

Figure 2

Distribution of total LCTs adopted by rice farmers in Hunan province 